\title{
Improved sensitivity and specificity for prostate cancer diagnosis based on the urine PCA3/PSA ratio acquired by sequence-specific RNA capture
}

\author{
KEWEN ZHENG ${ }^{1 *}$, YALING DOU ${ }^{2 *}$, LINFU HE $^{3}$, HANZHONG LI $^{1}$, ZHICAI ZHANG ${ }^{3}$, \\ YU CHEN $^{2}$, ALI YE ${ }^{2}$, WENJING LIU ${ }^{2}$ and LINGJUN KONG ${ }^{2}$ \\ ${ }^{1}$ Urology Department and ${ }^{2}$ Laboratory Medicine Department, Peking Union Medical College Hospital, \\ Chinese Academy of Medical Science and Peking Union Medical College, Beijing 100730; \\ ${ }^{3}$ Institute of Bioengineering, Jiangsu University, Zhenjiang, Jiangsu 212013, P.R. China
}

Received June 7, 2015; Accepted July 17, 2015

DOI: 10.3892/or.2015.4266

\begin{abstract}
Prostate cancer antigen 3 (PCA3) is a non-coding RNA fragment that is overexpressed in prostate cancer cells. However, the clinical applications of PCA3 are highly limited due to the instability of RNA and the lack of reliable and efficient RNA extraction and purification methods. Thus, in the present study, we compared three different methods of RNA extraction to further confirm the higher yield of commercial magnetic beads with poly-T functionalization and a capturer strand. The current protocols for RNA extraction of i) the phenol-chloroform method, ii) the affinity column method and iii) magnetic beads with poly-T functionalization and a capturer strand were applied separately for RNA extraction in urine samples. Reverse transcription-quantitative polymerase chain reaction was performed to evaluate the yield of the three methods of RNA extraction. Furthermore, 52 urine samples after prostate massage from patients suspected of a diagnosis of prostate cancer were collected. The Mag-Cap method and RT-PCR were applied to obtain the PCA3 score. The clinical value of the PCA3 score was investigated by comparison with the pathology of the prostate biopsy. The yield of the Mag-Cap method was higher than that of the phenol-chloroform method and commercial kits. Thirty-four patients were pathologically diagnosed with prostate cancer and 18 with benign prostatic hyperplasia (BPH). It was confirmed that the median PCA3
\end{abstract}

Correspondence to: Professor Hanzhong Li, Urology Department, Peking Union Medical College Hospital, Chinese Academy of Medical Science and Peking Union Medical College, 1 Shuai Fu Yuan, Wangfujing, Dongcheng, Beijing 100730, P.R. China

E-mail: lihanzhong_pumc@163.com

*Contributed equally

Key words: magnetic beads, prostate cancer antigen 3, prostate cancer, diagnosis score was higher among the prostate cancer patients than those with benign disease ( 53.5 vs. $17, \mathrm{p}=0.000$ ). A sensitivity of $82.4 \%$ and a specificity of $77.8 \%$ were obtained when the cut-off value for the PCA3 score was 28.5. The Mag-Cap method was found to be more efficient for RNA extraction. The urinary PCA3 score is a promising method for prostate cancer screening, detection and diagnosis, and has the potential to reduce unnecessary prostate biopsies.

\section{Introduction}

Prostate cancer remains challenging to clinical oncologists due to the fact that it has the highest incidence and second highest mortality rate among all cancer types for males in developed countries (1-3). In China, the incidence of prostate cancer is only lower than malignant tumors of the lung, stomach, esophagus, colon/rectum and liver (4). However, the incidence rate of prostate cancer is rising significantly. It is expected that the incidence of prostate cancer in China will reach 40/100,000 males in 2020, with annual new cases estimated at 350,000.

Prostate cancer is among the few cancers that can be screened and detected at an early stage (5). Prostate-specific antigen (PSA) has been widely accepted for prostate cancer screening (6-9). As a protein secreted only inside the prostate glands (10), its presence in blood/serum is trivial for healthy subjects. An abnormally high serum PSA level is evidence of a prostate lesion or a disorder such as prostate cancer. However, the application of PSA for prostate cancer diagnosis remains controversial. The debates are mainly focused on the poor sensitivity and specificity and the resulting over-diagnosis (11).

An alternative for PSA screening is prostate cancer antigen 3 (PCA3). PCA3 is a non-coding RNA expressed inside the prostate gland (12). Overexpression of PCA3 is common among prostate cancer patients (13-17). PCA3 is reported to be more cancer-specific, and thus a promising nextgeneration marker for prostate cancer screening (18-21). With higher specificity than PSA, PCA3 is expected to play more important roles in clinical practice such as prostate cancer screening, grading and recurrence monitoring (22). However, the quantification of PCA3 remains difficult due to poor RNA 
stability and lack of a purification method from complex matrix.

Nanotechnology has highly influenced biomedical research and clinical laboratory practice (23-25). Magnetic beads are nano-sized or micro-sized ferromagnetic iron oxide particles. Functionalized magnetic beads coated with antibodies or oligonucleotides have been widely used for the purification, extraction and detection of biomolecules $(26,27)$. We herein report a general method for RNA extraction based on magnetic beads and capturer strands, and its application for prostate cancer screening and diagnosis. As shown in Fig. 1, magnetic beads covalently conjugated to poly-T strands were incubated with the capturing strand (capturer) which involves poly-A and a sequence that is complementary to part of the target sequence (e.g., PSA or PCA3). The capturer is then immobilized on the magnetic beads through A-T pairing. The beads are incubated with the sample, through which the target sequences are captured by hybridization. Finally the beads with target immobilization are precipitated by magnetic attraction and carefully washed so that the interference sequences are removed with washing buffer. The target strand is eluted by heat-denaturation at an appropriate temperature.

\section{Patients and methods}

Patients and sample acquisition. Prostate cancer cell line 22RV1 (Institute of Biochemistry and Cell Biology CAS, cat. TCHu100) was cultured in RPMI-1640 media that contained bovine serum $(100 \mathrm{ml} / \mathrm{l})$ (both from Hyclone) and penicillin (100 U/ml; Sigma-Aldrich) at $37^{\circ} \mathrm{C}$ and with $50 \mathrm{ml} / \mathrm{CO}_{2}$. Female urine samples were collected in an RNAse-free vial. Patients enrolled in the study included 34 pathologically diagnosed primary prostate cancer patients and 18 patients with benign prostatic hyperplasia $(\mathrm{BPH})$. All patients were enrolled at Peking Union Medical College Hospital. For males, urine samples of 20-30 ml were collected after prostate massage (28). Urine samples from both male and female participants were aliquoted; an aliquot of $5 \mathrm{ml}$ urine was mixed with storage buffer (100 mM Tris-HCl, $500 \mathrm{mM} \mathrm{LiCl,} 10 \mathrm{mM}$ EDTA, $\mathrm{pH} 7.5,1 \%$ lithium dodecyl sulfate, $5 \mathrm{mM}$ dithiothreitol) (all chemicals from Sigma-Aldrich) in a 1:1 ratio. RNA extraction occurred within $4 \mathrm{~h}$ after sample collection. Urine samples were stored at $4^{\circ} \mathrm{C}$ for short term storage or at $-80^{\circ} \mathrm{C}$ for long term storage.

The study was approved by the Ethics Committee of Peking Union Medical College Hospital. All participants provided their written informed consent to participate in this study.

Phenol-chloroform extraction of RNA. The untreated female urine sample $\left(0.5 \mathrm{ml}\right.$ with the addition of $10^{4} 22 \mathrm{RV} 1$ cells $)$ was centrifuged for $5 \mathrm{~min}\left(3,500 \mathrm{rpm}, 4^{\circ} \mathrm{C}\right)$; the supernatant was discarded. The sample was mixed with $1 \mathrm{ml}$ TRIzol (Life Technologies) and incubated for $5 \mathrm{~min}$ at ambient temperature. The mixture was added with $200 \mu \mathrm{l}$ chloroform (Sigma-Aldrich), vortexed for $15 \mathrm{sec}$ and incubated for $3 \mathrm{~min}$ at ambient temperature. The mixture was centrifuged for $15 \mathrm{~min}\left(13,000 \mathrm{rpm}, 4^{\circ} \mathrm{C}\right)$. The aqueous layer was transferred to an RNAse-free vial and mixed with isopropanol of the same volume. The mixture was gently shaken and incubated for $10 \mathrm{~min}$. The mixture was centrifuged for $15 \mathrm{~min}(13,000 \mathrm{rpm}$, $4^{\circ} \mathrm{C}$ ), the supernatant was discarded, $50 \mu 1$ of $70 \%$ ethanol was added and the vial was gently shaken. The mixture was centrifuged for another $5 \mathrm{~min}\left(13,000 \mathrm{rpm}, 4^{\circ} \mathrm{C}\right)$, and the supernatant was discarded. The vial was dried with a vacuum and the vial was rehydrated with $500 \mu \mathrm{l}$ DEPC-treated RNAse-free water. The RNA solution was stored at $-20^{\circ} \mathrm{C}$.

RNA extraction by affinity column (SurePre Urine Exfoliated Cell RNA Purification kit by Thermo Fisher). The untreated female urine sample $\left(0.5 \mathrm{ml}\right.$ with the addition of $10^{4} 22 \mathrm{RV} 1$ cells) was centrifuged for $5 \mathrm{~min}\left(3,500 \mathrm{rpm}, 4^{\circ} \mathrm{C}\right)$; the supernatant was discarded. The sample was mixed with $500 \mu 1 \mathrm{TRK}$ buffer, and mixed by pipetting. The sample was centrifuged for 3 min ( $\geq 14,000 \mathrm{rpm}$, ambient temperature). An equal volume of anhydrous ethanol was added and mixed by vortexing for $20 \mathrm{sec}$. The mixture was transferred to the affinity column, followed by centrifugation for $1 \mathrm{~min}(10,000 \mathrm{rpm}$, ambient temperature), and the effluent was discarded. RNA wash buffer I $(300 \mu \mathrm{l})$ was added, followed by centrifugation for $1 \mathrm{~min}(10,000 \mathrm{rpm}$, ambient temperature), and the effluent was discarded. RNA wash buffer II $(500 \mu \mathrm{l})$ was added, followed by centrifugation for $30 \mathrm{sec}(10,000 \mathrm{rpm}$, ambient temperature), and the effluent was discarded; this step was repeated twice. The column was dried at an ambient temperature for $2 \mathrm{~min}$. The column was transferred to a new $1.5 \mathrm{ml}$ Ep tube, and $50 \mu \mathrm{l}$ of DEPC-treated RNAse-free water was added to the column to elute RNA by resting for $2 \mathrm{~min}$ and centrifugation for $1 \mathrm{~min}(10,000 \mathrm{rpm}$, ambient temperature). The RNA solution was stored at $-20^{\circ} \mathrm{C}$.

RNA extraction by Mag-Cap. Poly- $\mathrm{T}\left(\mathrm{T}_{25}\right)$ functionalized magnetic beads (10-20 mg; NEB) were washed twice with $100 \mu 1$ hybridization buffer (20 mM Tris, $\mathrm{pH} 7.5,100 \mathrm{mM}$ $\mathrm{NaCl})$. The beads were incubated with $100 \mu \mathrm{l}$ hybridization buffer that contained the capturer strand $(1.5 \mu \mathrm{M}$, PCA3 capturer: 5'-ATC TGT TTT CCT GCC CAT CCT TTA AGT TTA (A) $)_{30}$; PSA capturer: 5'-CGA ACT TGC GCA CAC ACG TCA TTG GAT TTA $(A)_{30}$. The beads were then mixed with $100 \mu 1$ hybridization buffer and $100 \mu 1$ treated urine sample. The vial was shaken to ensure full mixing and the mixture was heated for $30 \mathrm{~min}\left(62 \pm 1^{\circ} \mathrm{C}\right)$. The vial was cooled to ambient temperature for $30 \mathrm{~min}$, and the magnetic beads were collected by magnetic attraction. The beads were washed for three times with $100 \mu$ l elution buffer (10 mM Tris, $\mathrm{pH} 7.5)$. The beads were mixed with $50 \mu$ l elution buffer, which were incubated at $70^{\circ} \mathrm{C}$ for $5 \mathrm{~min}$, and the solution was collected and subjected to RNA quantification.

RNA extraction by Mag-Bind. The procedure was the same as the Mag-Cap process only the capturer strand was not contained.

RNA quantification. Purified RNA was converted to cDNA through reverse-transcription using a commercial kit (Fermentas). The quantification of cDNA was realized by qPCR. The primers and probe sequences (Life Technologies) are listed as following: primers for $P C A 3$ : forward, 5'-CCAG GAAGATCTGCATGGTGGG-3' and reverse, 5'-GATGACC CAAGATGGCGGC-3'; probe for PCA3: FAM-5'-GCACAGA GATCCCTGGGAGAAATGCC-TAMRA; primers for PSA: 


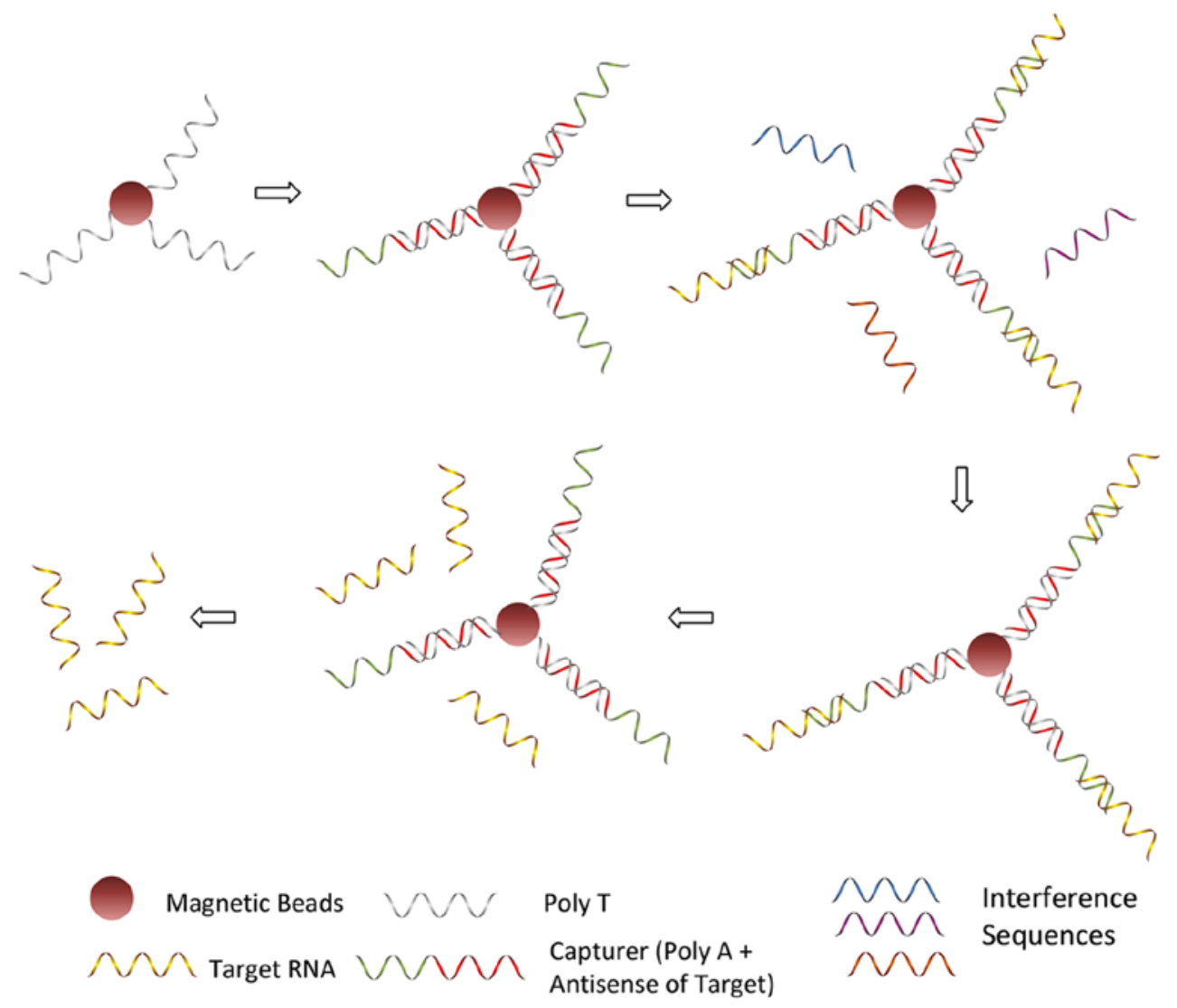

Figure 1. Mechanism for RNA extraction and purification via functionalized magnetic beads.

forward, 5'-CCT GCT CGG GTG ATT CTG-3' and reverse, 5'-GCC ACG ATG GTG TCC TTG AT-3'; probe for PSA: FAM-5'-GGG CCC ACT TGT CTG TAA TGG TGT GC-TAMRA. The PCR mixture was prepared using $2 \mu 110 \mathrm{X}$ PCR buffer (Roche), $4 \mu 1 \mathrm{MgCl}_{2}$ (25 mM; Sigma-Aldrich), $4 \mu \mathrm{l}$ dNTP solution (2.5 mM; Fermentas), $0.5 \mu$ l primer solutions $(10 \mu \mathrm{M}), 0.2 \mu \mathrm{l}$ probe solution $(10 \mu \mathrm{M}), 0.5 \mu \mathrm{l}$ Taq polymerase (Roche), $2 \mu \mathrm{l}$ cDNA solution and water to make the mixture $20 \mu \mathrm{l}$. One PCR cycle consisted of $95^{\circ} \mathrm{C}$ for $15 \mathrm{sec}$ and $60^{\circ} \mathrm{C}$ for $30 \mathrm{sec}$. Forty-five cycles were run for each PCR reaction. PCA3 scores were calculated using the following equation:

$$
\text { PCA3 score }=\frac{2^{C t-P C A 3}}{2^{C-P S A}}
$$

where $\mathrm{Ct}-\mathrm{PCA} 3$ is the $\mathrm{Ct}$ value during the amplification of the cDNA of PCA3; Ct-PSA is the Ct value during the amplification of the cDNA of PSA.

Statistical analysis. We used significance testing to compare the performance of Mag-Cap with the other methods. The power of PCA3 score for prostate cancer detection was evaluated using receiver operating characteristic (ROC) analysis. All statistical analysis was realized on SPSS (version 13.0).

\section{Results}

Comparison of Mag-Cap with other methods. We first evaluated Mag-Cap using artificial samples (prostate cancer cell line 22RV1 in 10 urine samples from healthy female subjects enrolled at Peking Union Medical College Hospital). The mRNA of PSA was extracted by phenol-chloroform method, affinity column (SurePre Urine Exfoliated Cell RNA Purification kit; Thermo Fisher) or Mag-Cap. The RNA molecules were quantified by quantitative PCR (qPCR) after reverse transcription, and $\mathrm{Ct}$ values are presented in Fig. 2. The medians of $\mathrm{Ct}$ values for phenol-chloroform extraction, affinity column and Mag-Cap were 28.3, 26.4 and 21.6, respectively. The difference between Mag-Cap and the other two extraction methods achieved statistical significance.

Comparison with a commercial kit. PCA3 in the 10 urine samples mentioned in the previous section was extracted by both Mag-Cap and a commercial magnetic bead-based RNA extraction kit (Mag-Bind mRNA kit; Omega Bio-Tek), and then quantified by qPCR. The results are shown in Fig. 3A. Medians of the $\mathrm{Ct}$ values of Mag-Cap and the Mag-Bind kit were 29.7 and 31.2, respectively. We also extracted and quantified PSA mRNA using the Mag-Bind kit. Median of the $\mathrm{Ct}$ values of 10 samples was 24.4 , compared with 21.6 when mRNA was extracted using Mag-Cap (Fig. 3B). The extraction yields of the two methods achieved significant difference for PCA3 and PSA extraction, respectively.

Clinical applications. We assessed the values of our method for prostate cancer prediction and diagnosis retrospectively. We enrolled 52 male patients including 34 with diagnosed prostate cancer and 18 with BPH. Their urine samples were collected after prostate massage; PCA3 and PSA mRNA were 


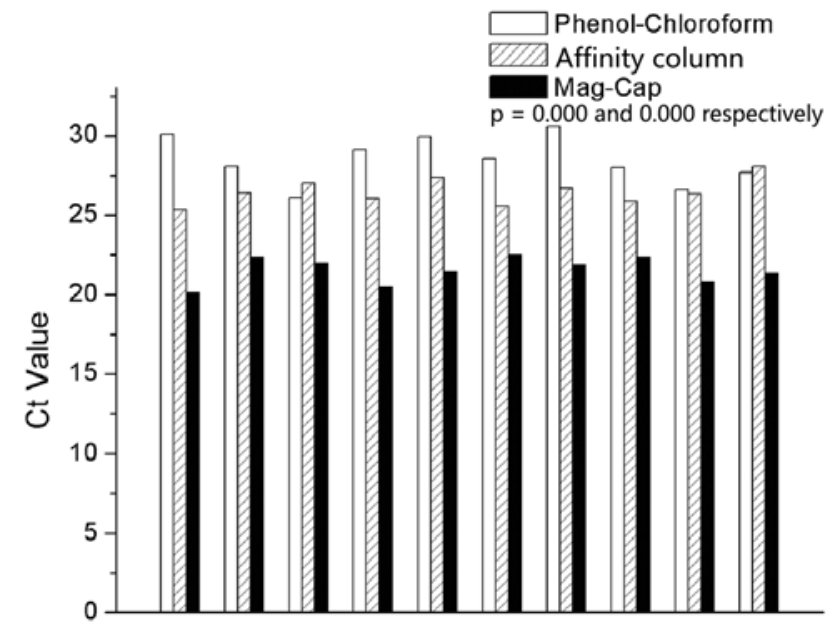

Figure 2. Comparison of three RNA extraction methods. Note that a lower $\mathrm{Ct}$ indicates a higher extraction yield.

extracted and quantified using Mag-Cap and real-time PCR, respectively. PCA3 scores were calculated as 1,000-fold of the ratio of PCA3 to PSA mRNA expression. The clinicopathological information and PCA3 scores of the patients enrolled are summarized in Tables I and II.

Median values of the PCA3 scores for patients with prostate cancer and BPH were 53.5 and 17, respectively. ROC analysis was applied to assess the performance of the PCA3 score as a prostate-specific cancer marker. The curve was plotted in Fig. 4 (blue trace). For comparison, we also plotted the ROC curve of total PSA in Fig. 4 (green trace). It was noted that the area under the curve (AUC) values for the PCA3 score and PSA were 0.831 and 0.655 , respectively. A sensitivity of $82.4 \%$ and a specificity of $77.8 \%$ were obtained when the cut-off value for the PCA3 score was 28.5.

\section{Discussion}

Researchers have focused on improving methods with higher specificity for prostate cancer diagnosis, and thus reduce unnecessary prostate biopsy. Plasma PSA has been widely used as a diagnostic marker for prostate cancer, but also shares certain deficiencies. PSA is prostate tissue-specific rather than cancer-specific, thus conditions such as prostatitis, benign prostatic hyperplasia, acute urinary retention, digital rectal examination, and cystoscopy can interfere. In addition, prostate cancer patients are not always characterized by abnormal plasma PSA. Although PSA derivatives have been developed to increase the specificity and sensitivity, such as the fPSA/ tPSA ratio, PSA density, and PSA velocity, the outcome is still unsatisfactory.

PCA3, located in 9q21-22, was originally named differential display code 3 (DD3) in 1999. PCA3 is a non-coding RNA expressed inside the prostate gland. The PCA3 gene is overexpressed specifically in human prostate cancer cells, and is thus considered to be an independent and stable marker for prostate cancer. The quantification of urine PCA3 after prostate massage is a non-invasive detection method, which can significantly improve the sensitivity, specificity and accuracy of prostate cancer diagnosis, and reduce unnecessary prostate biopsy. However, the quantification of PCA3 remains difficult due to poor RNA stability and the lack of a purification method from complex matrix.

In the present study, we present a general method for RNA extraction (Mag-Cap). A key step for the extraction of nucleic acids using magnetic beads is to immobilize a capturing strand which is complimentary to the target strand on the beads. A straight forward way is covalent conjugation, which is timeand labor-consuming and not general. Each target strand requires unique functionalized magnetic beads, which significantly limits its clinical applications. Our method avoided the covalent immobilization of various capturing strands, which were instead immobilized through DNA hybridization. This avoided the conjugation of the magnetic beads with various strands and is general for DNA, RNA and even artificial nucleic acids such as PNA and LNA.

We compared Mag-Cap with phenol-chloroform extraction, affinity column and a commercial magnetic bead-based nucleic acid extraction kit using controlled samples. The extraction yield was quantified by real-time PCR after reverse transcription. Ct values of the Mag-Cap group were 3-6 cycles less than those extracted by phenol-chloroform extraction and affinity column, which indicated that the yield of Mag-Cap was at least 8 (23) times higher than the other two theoretically. We also found that Mag-Cap was more efficient than the commercial Mag-Bind kit. All RNA sequences were
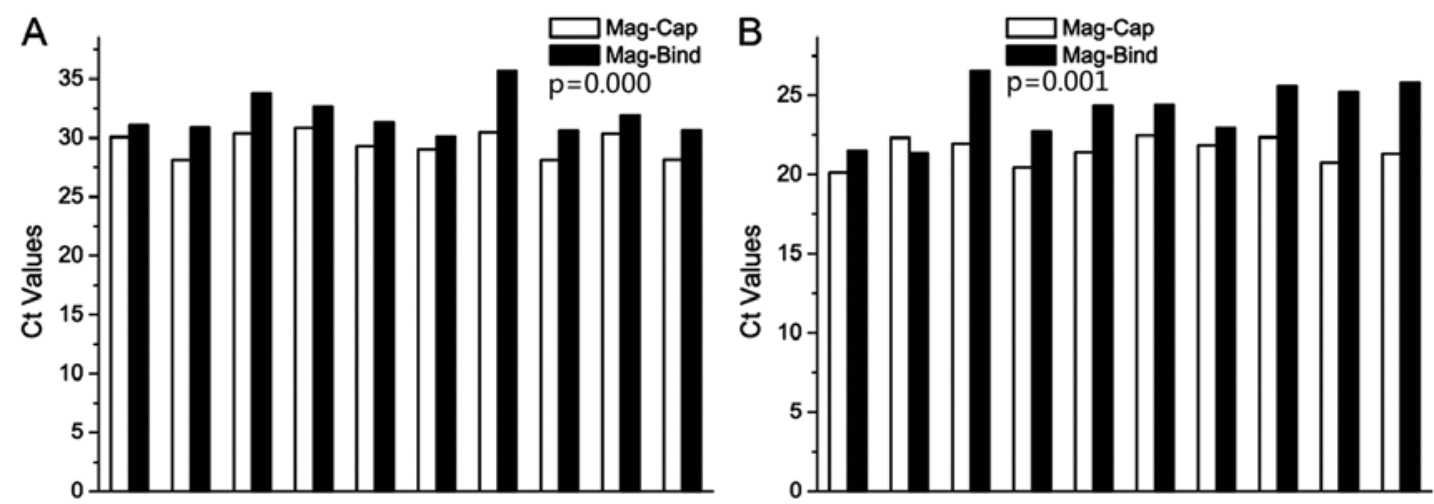

Figure 3. Comparison of Mag-Cap and Mag-Bind for the extraction of PCA3 (A) and PSA mRNA (B). PCA3, prostate cancer antigen 3; PSA, prostate-specific antigen. 
Table I. Clinicopathological information and PCA3 scores of the prostate cancer patients.

\begin{tabular}{|c|c|c|c|c|}
\hline $\begin{array}{l}\text { Patient } \\
\text { ID }\end{array}$ & $\begin{array}{c}\text { Age } \\
\text { (years) }\end{array}$ & Gleason score & $\begin{array}{l}\text { T-PSA }^{a} \\
(\mathrm{ng} / \mathrm{ml})\end{array}$ & PCA3 score \\
\hline C01 & 61 & $4+3$ & 8.8 & 41 \\
\hline $\mathrm{C} 02$ & 76 & $3+4$ & 37.5 & 79 \\
\hline $\mathrm{C} 03$ & 75 & $3+4$ & 4.4 & 33 \\
\hline $\mathrm{C} 04$ & 69 & $3+2$ & 4.8 & 39 \\
\hline $\mathrm{C} 05$ & 74 & NA & 4.1 & 59 \\
\hline $\mathrm{C} 06$ & 71 & $5+4$ & 31.4 & 103 \\
\hline $\mathrm{C} 07$ & 57 & $4+3$ & 4.7 & 66 \\
\hline $\mathrm{C} 08$ & 73 & $3+3$ & 11.7 & 35 \\
\hline C09 & 64 & $3+3$ & 7.7 & 23 \\
\hline $\mathrm{C} 10$ & 69 & $3+3$ & 6.2 & 70 \\
\hline C11 & 73 & $4+4$ & 5.0 & 85 \\
\hline $\mathrm{C} 12$ & 68 & NA & 5.7 & 19 \\
\hline C13 & 75 & $4+5$ & 10.0 & 226 \\
\hline C14 & 76 & $3+3$ & 3.2 & 137 \\
\hline $\mathrm{C} 15$ & 70 & $4+4$ & 206.8 & 48 \\
\hline C16 & 64 & $4+3$ & 33.3 & 71 \\
\hline $\mathrm{C} 17$ & 75 & NA & 6.4 & 64 \\
\hline C18 & 78 & $3+4$ & 0.2 & 33 \\
\hline C19 & 70 & $3+3$ & 14.8 & 29 \\
\hline $\mathrm{C} 20$ & 59 & $3+3$ & 12.8 & 88 \\
\hline $\mathrm{C} 21$ & 75 & $4+5$ & 27.3 & 91 \\
\hline $\mathrm{C} 22$ & 64 & $4+3$ & 33.3 & 48 \\
\hline $\mathrm{C} 23$ & 59 & $3+3$ & 12.8 & 0 \\
\hline $\mathrm{C} 24$ & 70 & $3+3$ & 14.8 & 59 \\
\hline $\mathrm{C} 25$ & 64 & $3+3$ & 7.7 & 33 \\
\hline $\mathrm{C} 26$ & 58 & NA & 361.6 & 68 \\
\hline $\mathrm{C} 27$ & 75 & $4+5$ & 27.3 & 69 \\
\hline C28 & 75 & $3+4$ & 4.4 & 83 \\
\hline C29 & 76 & $3+4$ & 37.5 & 73 \\
\hline C30 & 73 & $3+3$ & 11.7 & 0 \\
\hline C31 & 57 & $4+3$ & 4.7 & 33 \\
\hline C32 & 66 & NA & 8.2 & 36 \\
\hline C33 & 71 & $3+4$ & 24.3 & 0 \\
\hline C34 & 70 & $3+3$ & 12.9 & 24 \\
\hline
\end{tabular}

${ }^{\text {aT-PSA }}$ is the total PSA serum level, including both free and bound form. NA, not available; PCA3, prostate cancer antigen 3.

non-specifically extracted. Those unwanted nucleic acids might induce interference for further analysis.

We finally applied our method for PCA3 score measurement of clinical samples. The PCA3 score has been widely accepted as a more specific marker for prostate cancer screening. Irreproducibility and poor RNA extraction and detection limit the clinical applications of the PCA3 score (29-31). We applied our method for PCA3 score testing retrospectively and assessed its value for prostate cancer diagnosis by ROC analysis. The AUC value was over 0.83, while AUC of the serum total PSA level was 0.66 , which is consistent with previous studies (32).
Table II. Clinicopathological information and PCA3 scores of the BPH patients.

\begin{tabular}{lcccr}
\hline Patient ID & $\begin{array}{c}\text { Age } \\
\text { (years })\end{array}$ & $\begin{array}{c}\text { Pathological } \\
\text { diagnosis }\end{array}$ & $\begin{array}{c}\text { T-PSA } \\
(\mathrm{ng} / \mathrm{ml})\end{array}$ & PCA3 score \\
\hline B01 & 71 & BPH & 7.1 & 20 \\
B02 & 72 & BPH & 1.9 & 18 \\
B03 & 72 & BPH & 3.1 & 28 \\
B04 & 58 & BPH & 0.6 & 13 \\
B05 & 74 & BPH & 2.1 & 9 \\
B06 & 78 & BPH & 11.2 & 18 \\
B07 & 62 & BPH & 7.4 & 8 \\
B08 & 60 & BPH & 25.5 & 45 \\
B09 & 89 & BPH & 19.7 & 11 \\
B10 & 69 & BPH & 10.6 & 51 \\
B11 & 74 & BPH & 10.1 & 16 \\
B12 & 68 & BPH & 6.0 & 3 \\
B13 & 71 & BPH & 9.8 & 0 \\
B14 & 74 & BPH & 10.1 & 23 \\
B15 & 69 & BPH & 10.6 & 11 \\
B16 & 40 & BPH & 1.2 & 2 \\
B17 & 74 & BPH & 3.4 & 32 \\
B18 & 71 & BPH & 7.1 & 61 \\
\hline
\end{tabular}

PCA3, prostate cancer antigen 3; $\mathrm{BPH}$, benign prostatic hyperplasia.

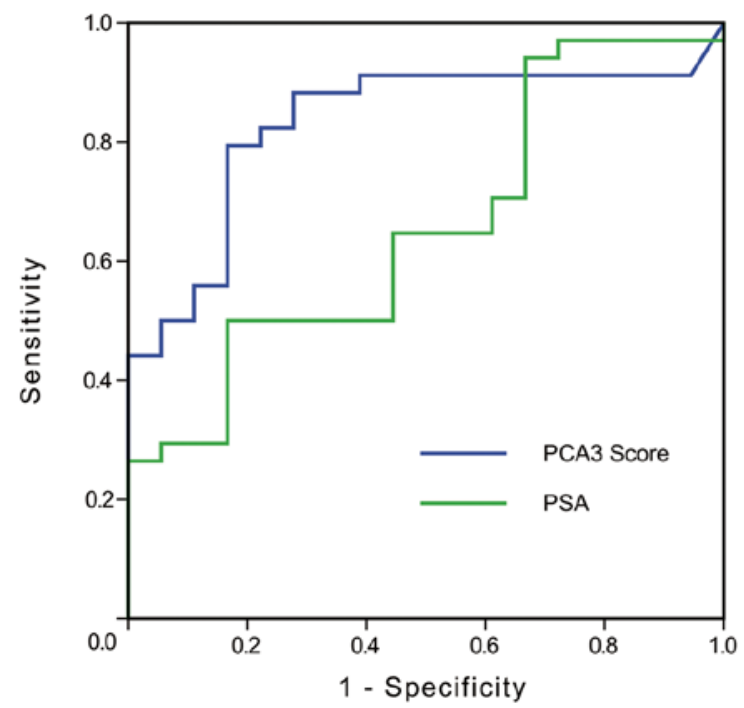

Figure 4. ROC curves of the PCA3 score (blue) and total PSA (green) for prostate cancer diagnosis. ROC, receiver operating characteristics; PSA, prostate-specific antigen; PCA3, prostate cancer antigen 3.

In this research, 2 cases of prostate cancer patients with serum tPSA $<4 \mu \mathrm{g} / 1$ were both diagnosed with prostate cancer using the urinary PCA3 score when the cutoff value was 28.5, and 16 cases of prostate cancer patients with serum tPSA $4-10 \mu \mathrm{g} / 1$. This indicates that the urinary PCA3 score contributed to the diagnosis of prostate cancer with normal serum tPSA or patients in the gray area. Cases (5 of 7) of BPH patients with serum tPSA $>10 \mu \mathrm{g} / 1$ were excluded as prostate 
cancer using the urinary PCA3 score method, which indicates that urinary PCA3 scores contribute to exclude prostate cancer in patients with elevated serum tPSA, thus reducing unnecessary prostate biopsy.

In conclusion, we present a novel RNA extraction technique based on magnetic beads while avoiding tedious covalent functionalization of the beads with nucleic acids. We found that the RNA extraction yields were higher than traditional phenolchloroform extraction, affinity column and a commercial RNA purification kit based on magnetic beads. We also report its application for PCA3 RNA detection. At the optimized condition, the sensitivity and specificity were 82.4 and $77.8 \%$, respectively. However, this result was limited due to the small sample. Fortunately, this research is still ongoing, and further investigation is warranted for the application of the urinary PCA3 score in the diagnosis of prostate cancer.

\section{Acknowledgements}

The authors thank Xiangyun Qu and Yong Qin for the helpful discussions.

\section{References}

1. Siegel R, DeSantis C, Virgo K, Stein K, Mariotto A, Smith T, Cooper D, Gansler T, Lerro C, Fedewa S, et al: Cancer treatment and survivorship statistics, 2012. CA Cancer J Clin 62: 220-241, 2012.

2. Jemal A, Bray F, Center MM, Ferlay J, Ward E and Forman D: Global cancer statistics. CA Cancer J Clin 61: 69-90, 2011.

3. Surveillance E; End Results (SEER) Program: (www.seer.cancer. gov) SEER*Stat Database: Mortality - All COD, Aggregated With State, Total U.S. (1969-2010) <Katrina/Rita Population Adjustment $>$, National Cancer Institute, DCCPS, Surveillance Research Program, Surveillance Systems Branch, released April 2013. Underlying mortality data provided by NCHS (www.cdc. gov/nchs).

4. Chen W, Zheng R, Zhang S, Zhao P, Li G, Wu L and He J: The incidences and mortalities of major cancers in China, 2009. Chin J Cancer 32: 106-112, 2013.

5. Smith RA, Cokkinides V and Eyre HJ: Cancer screening in the United States, 2007: A review of current guidelines, practices, and prospects. CA Cancer J Clin 57: 90-104, 2007.

6. Slawin KM, Ohori M, Dillioglugil O and Scardino PT: Screening for prostate cancer: An analysis of the early experience. CA Cancer J Clin 45: 134-147, 1995.

7. Catalona WJ, Richie JP, Ahmann FR, Hudson MA, Scardino PT, Flanigan RC, deKernion JB, Ratliff TL, Kavoussi LR, Dalkin BL, et al: Comparison of digital rectal examination and serum prostate specific antigen in the early detection of prostate cancer: Results of a multicenter clinical trial of 6,630 men. J Urol 151: 1283-1290, 1994.

8. Cher ML and Carroll PR: Screening for prostate cancer. West J Med 162: 235-242, 1995.

9. Schmidt JD: Clinical diagnosis of prostate cancer. Cancer 70 (Suppl 1): 221-224, 1992.

10. Lilja H: Biology of prostate-specific antigen. Urology 62 (Suppl 1): 27-33, 2003.

11. Yates DR and Catto JW: Distinct patterns and behaviour of urothelial carcinoma with respect to anatomical location: How molecular biomarkers can augment clinico-pathological predictors in upper urinary tract tumours. World J Urol 31: 21-29, 2013.

12. Clarke RA, Zhao Z, Guo AY, Roper K, Teng L, Fang ZM, Samaratunga H, Lavin MF and Gardiner RA: New genomic structure for prostate cancer specific gene PCA3 within BMCC1: Implications for prostate cancer detection and progression. PLoS One 4: e4995, 2009
13. Roddam AW, Duffy MJ, Hamdy FC, Ward AM, Patnick J, Price CP, Rimmer J, Sturgeon C, White P and Allen NE; NHS Prostate Cancer Risk Management: Use of prostate-specific antigen (PSA) isoforms for the detection of prostate cancer in men with a PSA level of $2-10 \mathrm{ng} / \mathrm{ml}$ : Systematic review and meta-analysis. Eur Urol 48: 386-399, 2005.

14. Bussemakers MJ, van Bokhoven A, Verhaegh GW, Smit FP, Karthaus HF, Schalken JA, Debruyne FM, Ru N and Isaacs WB: DD3: A new prostate-specific gene, highly overexpressed in prostate cancer. Cancer Res 59: 5975-5979, 1999.

15. Hessels D, Klein Gunnewiek JM, van Oort I, Karthaus HF, van Leenders GJ, van Balken B, Kiemeney LA, Witjes JA and Schalken JA: DD3(PCA3)-based molecular urine analysis for the diagnosis of prostate cancer. Eur Urol 44: 8-16, 2003.

16. Schalken JA, Hessels D and Verhaegh G: New targets for therapy in prostate cancer: Differential display code 3 (DD3(PCA3)), a highly prostate cancer-specific gene. Urology 62 (Suppl 1): 34-43, 2003.

17. de Kok JB, Verhaegh GW, Roelofs RW, Hessels D, Kiemeney LA, Aalders TW, Swinkels DW and Schalken JA: DD3(PCA3), a very sensitive and specific marker to detect prostate tumors. Cancer Res 62: 2695-2698, 2002.

18. Day JR, Jost M, Reynolds MA, Groskopf J and Rittenhouse H: PCA3: From basic molecular science to the clinical lab. Cancer Lett 301: 1-6, 2011.

19. Ploussard G and de la Taille A: Urine biomarkers in prostate cancer. Nat Rev Urol 7: 101-109, 2010.

20. Roobol MJ: Contemporary role of prostate cancer gene 3 in the management of prostate cancer. Curr Opin Urol 21: 225-229, 2011.

21. Roobol MJ, Haese A and Bjartell A: Tumour markers in prostate cancer III: Biomarkers in urine. Acta Oncol 50 (Suppl 1): 85-89, 2011.

22. Marks LS, Fradet Y, Deras IL, Blase A, Mathis J, Aubin SM, Cancio AT, Desaulniers M, Ellis WJ, Rittenhouse H, et al: PCA3 molecular urine assay for prostate cancer in men undergoing repeat biopsy. Urology 69: 532-535, 2007.

23. Janegitz BC, Cancino J and Zucolotto V: Disposable biosensors for clinical diagnosis. J Nanosci Nanotechnol 14: 378-389, 2014.

24. McCarroll J, Teo J, Boyer C, Goldstein D, Kavallaris M and Phillips PA: Potential applications of nanotechnology for the diagnosis and treatment of pancreatic cancer. Front Physiol 5: 2, 2014.

25. Thakor AS and Gambhir SS: Nanooncology: The future of cancer diagnosis and therapy. CA Cancer J Clin 63: 395-418, 2013.

26. Chan CP, Cheung YC, Renneberg R and Seydack M: New trends in immunoassays. Adv Biochem Eng Biotechnol 109: 123-154, 2008.

27. Sandhu A, Handa H and Abe M: Synthesis and applications of magnetic nanoparticles for biorecognition and point of care medical diagnostics. Nanotechnology 21: 442001, 2010.

28. Casadio V, Calistri D, Salvi S, Gunelli R, Carretta E, Amadori D, Silvestrini R and Zoli W: Urine cell-free DNA integrity as a marker for early prostate cancer diagnosis: A pilot study. Biomed Res Int 2013: 270457, 2013.

29. Bettegowda C, Sausen M, Leary RJ, Kinde I, Wang Y, Agrawal N, Bartlett BR, Wang H, Luber B, Alani RM, et al: Detection of circulating tumor DNA in early- and late-stage human malignancies. Sci Transl Med 6: 224ra24, 2014.

30. Ahyai SA, Graefen M, Steuber T, Haese A, Schlomm T, Walz J, Köllermann J, Briganti A, Zacharias M, Friedrich MG, et al: Contemporary prostate cancer prevalence among T1c biopsy-referred men with a prostate-specific antigen level $\leq 4.0 \mathrm{ng}$ per milliliter. Eur Urol 53: 750-757, 2008.

31. Thompson IM, Pauler DK, Goodman PJ, Tangen CM, Lucia MS, Parnes HL, Minasian LM, Ford LG, Lippman SM, Crawford ED, et al: Prevalence of prostate cancer among men with a prostate-specific antigen level $\leq 4.0 \mathrm{ng}$ per milliliter. N Engl J Med 350: 2239-2246, 2004.

32. Groskopf J, Aubin SM, Deras IL, Blase A, Bodrug S, Clark C, Brentano S, Mathis J, Pham J, Meyer T, et al: APTIMA PCA3 molecular urine test: development of a method to aid in the diagnosis of prostate cancer. Clin Chem 52: 1089-1095, 2006. 